\title{
Feeling Like a Clerk in H. G. Wells
}

\author{
Richard Higgins
}

We're all respectable householders-that's to say Tories, yes-men and bumsuckers.

- George Orwell, Coming Up for Air (16)

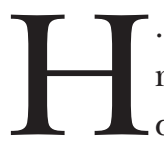

. G. Wells was an explosively moody man, subject to caprice, reckless passion, and perverse, self-defeating acts of imprudence (MacKenzie xxx). His powerful emotions led to resentment and irresponsibility as a clerk, to rebellion and failure at university, and to life-long philandering that threatened his relations with those closest to him. Let's begin, then, with an interpretation of these emotions, the impulses that he would later spend so much time describing in his autobiographies, Experiment in Autobiography (1934) and H. G. Wells in Love (1984). I would contend that his impulses were largely the product of his lower-middle-class origins, both a reaction to his strained circumstances and a way to distinguish himself from others like him. These impulses led to reckless acts that deflected his frustration and shame as a member of the lower middle class. From his own perspective, though, they helped to make him an "originative intellectual worker," emerging from a sea of small-minded clerks and students (Experiment 17). Even as they resulted in acts of self-sabotage, they masqueraded as sui generis emotions that, like the inspirations of a self-made man, marked him as something more than a product of his class.

And yet, even late in life, Wells's impulses were bound up with

ABSTRACT: In three turn-of-the-century novels about clerks and scholarship boys, H. G. Wells illustrates the emotional impact of social hierarchies on individual lives. By portraying the conflicted, class-related emotions of lower-middle-class men, Wells departs from the common contemporary image of the clerk as a figure synonymous with his function. But Wells depicts other emotions-specifically, those associated with domesticity and recklessness - to push against what he sees as the classed nature of emotional lives. He rewrites Victorian domesticity as a zone of sexuality and desire for his lower-middle-class clerks, and he mobilizes an emergent cultural appreciation of recklessness to instill them with vitality. The "significant selves" that develop as a result help to offset their ultimate failure to escape their class. 
a deeply class-based sense of inadequacy. The strong dread of failure that was instilled in him as a product of the lower middle class was only incompletely transmuted into the romantic and sensual disillusionment of his middle age. The elusive and haunting love object he describes in his autobiography as the Lover-Shadow suggests the extent to which his success was accompanied by a sense of failure. The Lover-Shadow undermines the light-hearted pleasure with which Wells otherwise characterizes his infamous series of affairs in the posthumously published $H$. G. Wells in Love; his claims to "cool-hearted[ness]" are belied by the unsatisfied ache they inspire (Experiment 61). Interpreted variously as the natural consequence of his heterosexual desire or the cover story for his pathological needs, Wells saw the Lover-Shadow as a physical drive and a psychological ideal, both compelling and rationalizing his promiscuity. ${ }^{1}$ But the Lover-Shadow is not merely about sexual satisfaction. It represents Wells's persistent discontent, leading to uncontrollable obsession, distracting preoccupation, and unfulfilled need. He writes,

\footnotetext{
We play with the sexual side of the Lover-Shadow; we relieve and drug the dissatisfaction of our imaginations in a purely sexual adventure, and suddenly sex turns upon us and grips us. . . [B] efore we know where we are, the haunting deeper need to possess and be possessed, for good and all, that undying hunger of the soul for a commanding love-response, has laid hold upon us. . . It is a mental and aesthetic quite as much as a physical need. (H. G. Wells in Love 66-67)
}

This passage describes the state of being possessed by physical as well as mental and aesthetic hunger. ${ }^{2}$ Wells suggests such hungers are the consequences of his autonomy and progressiveness, side effects of his success. Yet his reckless pursuit of sexual satisfaction-of relief from "the dissatisfaction of our imaginations"-turns out to be as much the product of his class-inflected sense of inadequacy as any of his other emotions. Meditating on the insufficiencies of his Lover-Shadow, he writes in H. G. Wells in Love of "the conviction of my own unworthiness" (203). "Sometimes," he continues, "I realize something in myself so silly, fitful and entirely inadequate to opportunity, that I feel even by my own standards I am not fit to live" (203).

In this essay I propose to get a better view of the lived experience of class through a close examination of the relationship between class and the emotions in Wells's work. ${ }^{3}$ My goal, though, is not simply to describe the effects of class on the emotions; rather, I hope to demonstrate, as I think Wells does, that the range and complexity of the 
emotions have much to add to conventional class analysis. Many of these emotions are more prosaic than we have been accustomed to observemore passive frustration, for example, than class rage. As Sianne Ngai contends, "the nature of the sociopolitical itself has changed in a manner that both calls forth and calls upon a new set of feelings-ones less powerful than the classical political passions, though perhaps more suited, in their ambient, Bartlebyan, but still diagnostic nature, for models of subjectivity, collectivity, and agency" (5). Ngai's reference to Bartleby is not an accident; the new feelings she describes were (and continue to be) a profound part of the lower-middle-class experience, making members of this class exemplary vehicles for exploring the significance of the emotions for an analysis of what it means to experience oneself as a member of a particular class. ${ }^{4}$

I focus on the appearance of these new feelings in a sequence of novels Wells wrote about male clerks and scholarship boys in the 1890s and 1900s-among them, Love and Mr. Lewisham (1900), Kipps (1905), and The History of Mr. Polly (1910). Many of the characters in these novels are modeled on Wells's own lower-middle-class past. Through them, the novelist expresses the muted outbursts of anger, the veiled feelings of frustration and shame, as well as the small rebellions, the occasional bravado, and the flights of fantastic ambition and self-aggrandizing narcissism that he sees as characterizing the emotional lives of lower-middle-class men. ${ }^{5}$ Wells not only chronicles the material conditions of everyday life, he also helps us understand the extent to which class difference is a matter of how personal emotions fit in the social order (Sennett 258; Foote 66).

Wells demonstrates how his characters are subjected to socially conditioned feelings, emotions of class that make what is rotten in society also rotten in the self. Through class-coded emotions such as shame, ambition, and frustration, he illustrates the profound impact of social hierarchies on individual lives. But as much as Wells opens the door to the recognition that all emotion may be in some way social, he asserts that certain emotions can remain untouched by class experience. He uses emotions related to domestic life and those associated with acts of recklessness to push against what he sees as the social contamination (or the classed nature) of emotion. Wells imagines Victorian domesticity as an alternative to the humiliation of the marketplace experienced by the lower-middle-class clerk, and he mobilizes an emergent cultural appreciation of recklessness and rashness to instill vitality in his clerks. ${ }^{6}$ The 
emotions that lead to recklessness cannot remain free from social imperatives, but Wells's narratives expand the range of their emotions and thereby enlarge our view of their lives, defying centuries of ideological indifference to the emotions of the lower classes (Gross 168-78). As Ngai argues, however, emotions frequently obstruct agency and undermine understanding. Wells's domestic worlds elicit unnerving and even deplorable emotions, for example. But ugly as they may be, they help reveal not only the middle-class values that shape lower-middle-class life, but also the self-loathing that has so often come to define the lower middle class.

According to Pierre Bourdieu, "The petit bourgeois is a proletarian who makes himself small to become bourgeois. ... With his petty cares and petty needs, the petit bourgeois is indeed a bourgeois "writ small'" (338). Like other writers from the lower middle class, Bourdieu, the son of a postman, reserves particular scorn for the class of his origins (Fowler). This disdain derives, in part, from the class betrayal built into the very definition of being lower middle class. Ambitious or successful lower-middle-class individuals no longer see themselves as lower middle class-hence the contempt they so often feel toward their former lives. Wells's own contempt is often apparent in his social comedies. But he is clearly not satisfied with simply representing the place of members of the lower middle class as diminutive. Many novels of the late-Victorian period, such as George and Weedon Grossmith's Diary of a Nobody (1892), or the fictional life of Mr. Bailey, Grocersatirized by George Gissing in New Grub Street (1891), are interested in the ordinary, material lives of clerks. Wells, by contrast, uses emotions to make his clerks seem much richer, more significant, and more complicated than they might have seemed in the hands of other authors. ${ }^{7}$

\section{Shame at Home}

Kipps has been described as the most naïve of Wells's clerkly protagonists (Green 10). This impression is largely the result of the shame with which Kipps responds to the sudden wealth he gains from a surprise inheritance. Even more than Wells's other social comedies, Kipps is about the persistence of class. Where the surprise inheritance in most Victorian novels might confirm the social position of a naturally upper-middle-class character, Kipps's inheritance elevates a character who embodies the lower middle class. The deeply ingrained habits of class prevent him from becoming what his fortune ordinarily 
implies. Kipps thus wanders bewildered and hurt through the wilderness of the middle class before slowly coming to realize that domestic satisfaction lies with the lower middle class. To this end, Wells rewrites the domestic - and the lower middle class's relation to it-as a place of sexual desire, pleasure, and rebellion. (This is of a piece with Wells's critique of marriage as a "correlative of private proprietorship" and his urgent advocacy of an "active sexual life," which came to be more and more pronounced in his work and thought [Experiment 474-75].) While Kipps's class mobility is muted, his marriage to Ann Pornick ultimately represents an attempt to transform the many shames that Wells saw underlying the social authority of the middle-class home and the pieties of Victorian domesticity.

When Wells discusses Kipps's socioeconomic destiny, he emphasizes its inevitability: "Inexorable fate had appointed him to serve his country in commerce, and the same national bias towards private enterprise and leaving bad alone, which had left his general education to Mr. Woodrow, now indentured him firmly into the hands of Mr. Shalford of the Folkestone Drapery Bazaar" (33). Once Kipps is indentured, the dull routine of his days makes him gloomy and even resentful:

\footnotetext{
A vague self-disgust that shaped itself as an intense hatred of Shalford and all his fellow-creatures filled the soul of Kipps. ... Dimly he perceived the thing that had happened to him, how the great stupid machine of retail trade had caught his life into its wheels, a vast, irresistible force which he had neither strength of will nor knowledge to escape. (43-44)
}

His emotional life as a clerk is suffused with a sense of his impotent immobility.

In the face of such an existence, Kipps's very emergence from the shop appears as a form of recklessness. Indeed, the impulsive, all-night drinking binge with the unemployed actor Chitterlow coincides with the surprise inheritance. But I would like to step back a bit in the plot and consider the one other, earlier way that Kipps manages to escape the stasis of the shop. The adult educational woodworking course that Kipps begins on his one free evening a week seems as if it should draw him into a normative narrative of self-improvement. But the clerk only continues to attend the course because of his reckless, all-consuming crush on its young, shabbily genteel teacher. The course replicates the class dynamics and hierarchies of his service as a clerk, but in a different key. In the classroom, Kipps is acutely aware of the inferiority of his clothes, language, 
and education: he is like "a creature of the outer darkness blinking in an unsuspected light," who must remain silent in the classroom to conceal the "bottomless baseness" of "his tongue" (57). Likewise, he feels "pure and awe-stricken humility" in the presence of Helen Walshingham, his teacher (57). Yet even as his social inferiority to his teacher humiliates him, the erotic possibilities of the relationship counter that feeling by generating in him a sense of class transcendence.

One example illustrates how rashness changes the way that he and others view his class identity. Some time after Kipps begins furtively to hope for Helen's attentions, he is given the chance to act chivalrously by opening a classroom window for her: "It did not take Kipps a moment to grasp his opportunity. ... He felt his manhood was at stake" (59). In the process he cuts his hand, and the wound is subsequently dressed by Helen and her "freckled" friend. The scene is sexually charged, changing Helen's and her friend's view of Kipps, particularly after he keeps blood from dripping on the "floor of that cultured classroom" by licking his wound (60). The act of licking-"oh, don't," Helen exclaims-makes Kipps think of himself as particularly manly (60). The two women's ministrations to his wound further eroticize the process: the "young ladies became very intent on the knot" of the bandage, while Kipps "was very red and very intent on the two young ladies" (61). Through the intimacy of the event, Kipps's identity as a clerk is transformed; to Helen and her friend, he becomes something more than his socioeconomic position. Much as the Schlegel sisters view Leonard Bass in E. M. Forster's later Howards End (1910), they begin to see him as someone who is "misunderstood" and "too sensitive" for the demeaning life of a clerk (64).

This sense of himself as something more than his socioeconomic position inspires Kipps to imagine an alternative future for himself. After a conversation with some fellow clerks about the successful class mobility of Charles Dickens ("a labeler of blacking”), William Makepeace Thackeray (“'an artis' who couldn't sell a drawing”) and Samuel Johnson (who "walked to London without any boots"), Kipps begins to envision himself as a future "Nawther" (64):

After this there were times when Kipps had the pleasant sense that comes of attracting interest. He was a mute, inglorious Dickens, or at any rate something of that sort, and they were all taking him at that. The discovery of this indefinable "something in" him . . . did much to bridge the gulf between himself and Miss Walshingham. He was unfortunate, he was futile, but he was not "common." (65) 
The "discovery" of "something in him" makes available to Kipps a widening array of affects and experiences, changing his self-image as well as the way others perceive him. The episode suggests that something can be made from class experience, shaping but not standing in the way of success.

Following the arrival of his inheritance, however, the "something in him" that makes Kipps special evaporates, with the ironic effect of making him appear even more lower middle class than he was before. The money should insure his future domestic bliss with Helen, but instead it insidiously emphasizes their differing levels of education and sophistication, calling attention to the way he speaks and dresses and to the class of people with whom he associates. Installed in his mysterious grandfather's old-fashioned town home, for example, even "the rug, the fender, the mantel, and mirror, conspired with great success to make him look trivial and . . . mocked and made tremendous fun of him" (127). From here on out, people-including Helenfind him phony and ordinary, rather than a romantic character with a "sensitive" and "misunderstood" nature (64). Helen's attempts to reform him make him just another awkward man who can pay the bills, surrounded by a set of expectations he can barely understand but that nevertheless make him ashamed of himself. She "told him things about his accent; she told him things about his bearing, about his costume and his way of looking at things," that leave Kipps wounded: "She thrust the blade of her intelligence into the tenderest corners of Kipps' secret vanity; she slashed his most intimate pride to bleeding tatters" (183). His anticipation of domestic bliss with Helen becomes tainted with shame.

The home looms large in the cultural life of the nineteenthcentury clerk. Throughout the Victorian period, the home was identified as a zone of safety from the humiliations of the clerk's public role and as a place that underscored the clerk's diminution and feminization (Hammerton 294-95). (Dickens literalizes this set of associations in Great Expectations [1860-61] where Wemmick's castle is both his place of refuge and a feminizing miniature.) Kipps wants to preserve the erotic intensity of his classroom encounter with Helen in their future home, but he also needs that home to be a safe harbor from the shame that attends his awkward class status. As their wedding approaches, he becomes progressively alienated from her: the more she presses for a conventional, bourgeois life in London, and the more 
she confirms his inadequacy, the more he loses the sense of that special "something in him" that originally emboldened him. Kipps becomes increasingly estranged from himself, split between two worlds: one "constituting his primary world, his world of origin"; the other "the world of culture and refinement . . . a world, it was fast becoming evident, absolutely incompatible with the first" (216).

At the height of his self-estrangement, Kipps reencounters Ann Pornick, a woman from "his world of origin." Ann first awakened his sexuality as a young man and reappears in the plot to save him from Helen. With Ann, "Extraordinary impulses arose in neglected parts of Kipps' being" (201); she "called out all the least gentlemanly instincts of his nature. . . There was something warming about Ann" (202); "he wanted to hold her and be held by her, to kiss her again and again" (214). Ann, of course, is not only more sensual than Helen, she also doesn't challenge Kipps or remind him of his inadequacies. She "was possible to his imagination just exactly where Helen was impossible. More than anything else, she carried the charm of respect for him, the slightest glance of her eyes was balm for his perpetually wounded self-conceit" (210). Most importantly, she doesn't carry bourgeois manners and values into the home.

But even in this home, shame threatens to kill his desire. In choosing Ann, Kipps pursues a sexual desire that seems untouched by class. Yet here too he must come to terms with social imperatives regarding domesticity. This time, however, it is he who censures. Once they are married, Kipps bends to the will of the "Argus eyes of the social system" by building a new, ostentatious house to match his wealth (276). Ann, though, refuses to participate fully in Kipps's endeavor to make them middle class. At their lowest point Ann becomes "the source of all his shames" (304). In a pivotal scene she answers the door for visitors in her cleaning clothes and is mistaken for the maid. As a result of failing to be accepted by the middle-class community in which he lives, Kipps finds himself once again becoming estranged from his desire for another. He must then go through yet another transformation in class status by losing his fortune, returning to his origins, before he can fully accept his love for Ann. But in their mourning for the lost fortune, Wells idealizes their intimacy as though Kipps and Ann had discovered their own Lover-Shadows in each other: 
"We 'ave been 'appy, Ann ... some'ow ... togever."

And with that he and then she fell into a passion of weeping.

They clung very tightly together-closer than they had been since ever the first brightness of their married days turned to the gray of common life again. (313)

With this, Wells makes clear his ultimate claim that the emotions that keep a home intact are erotic and romantic ones and that they should always be protected from the contamination of the outside world.

But even with this point proved, Wells seems unsatisfied with his creation. It turns out that the lower-middle-class hero-a hero, in part, because he does not leave his class-is somewhat less than heroic. The narrator betrays his own ambivalence in a moment of putative sympathy regarding the "lumpish monster" of "Stupidity" that looms over Kipps and Ann: "I see through the darkness the souls of my Kippses as they are, as little pink strips of quivering, living stuff, as things like the bodies of little, ill-nourished, ailing, ignorant children-children who feel pain, who are naughty and muddle and suffer, and do not understand why" (306). While Wells blames stupidity and a stunted social system for the Kippses' plight, in the same passage he appeals to a readership who are "favoured" to apprehend "beauty" where the Kippses are not (306). The Kippses are made of "quivering, living stuff" capable of feeling and suffering, but they fail, Wells notes, to comprehend "the vision of the Grail that makes life fine for ever” (306). While Wells appreciates Kipps's emotion, he deplores the fact that he does not have the capacity for selfunderstanding. This disposition makes Wells's exploration of class all the more ambivalent. He clearly wants to assert that the values and emotions of the lower-middle-class home are superior, but the implied ideal of the passage is of an intellectual class whose values transcend socioeconomic status and whose members are more thoroughly autonomous.

\section{Recklessly Domestic}

Lewisham, of Love and Mr. Lewisham, is exactly the sort of intellectual Wells idealizes in Kipps. For Lewisham, the domestic is initially a threat to his class ambition, as are recklessness and the intensities it implies. Indeed, emotions of every kind constitute a direct threat to Lewisham's upward mobility. In contrast to Kipps, who has little hope of class mobility as a member of the proletarianized lower middle class, Lewisham belongs to the upwardly mobile lower middle class. An implacable Gradgrind, he actively converts the elements of his intel- 
lectual training into instrumentalized stepping-stones on the way to becoming homo economicus; he willingly objectifies himself for the promise of class mobility. Meanwhile, his powerful emotions, especially those related to his ambition and the shame it inspires, take on the character of hungers or uncontrollable forms of desire.

The central struggle of the novel, then, is between two narrative goals, one explicit and one implicit. In the first, Wells tries to impose a strict boundary between economically productive emotions and non- or anti-productive emotions, such as those associated with domesticity and rashness. But this project is driven by the second, implicit aim: to reconcile strong emotions with the social imperatives that have defined Lewisham's life. Throughout the novel, Lewisham cannot help but be reckless, for his recklessness coincides with his angry ambition and shame. Even when he marries and sets up house, his domestic environment fails to domesticate him. This is why Wells is so fond of recklessness, for it defies middle-class values and compensates for the compromises involved in seeking refuge in the domestic. But there are consequences for allowing rashness to coexist with domesticity, and Lewisham's recklessness risks destroying his domestic satisfaction. ${ }^{8}$

As in the other social comedies, strong emotion appears in Love and Mr. Lewisham as an enlivening influence in the form of erotic passion. Lewisham begins the novel as an assistant master of a grammar school who follows a strict schedule or "Schema" of self-improvement (2). But once he becomes distracted by a young woman and the surprising rush of sexual desire that she generates, Lewisham's future as a scholar is suddenly made to seem uncertain. The stakes are high in this scenario. Wells himself as a young instructor at Midhurst made a plan that he too called a schema. For Wells, like Lewisham, "every moment in the day had its task" with one goal in mind: "making a desperate get-away from the shop and the street" (Experiment 171). To Lewisham, the mechanism for getting away is a college degree. On one wall of his small room are the words "Knowledge is Power" and on another is a Time-Table for the completion of his studies and his goals for a degree. "To judge by the room," Wells writes, "Mr. Lewisham thought little of Love but much on Greatness" (1). This changes after he notices Ethel, a young, lower-middle-class woman from the London suburbs staying with nearby relatives.

Sexual desire in the novel may be irrational and overwhelming, but in its nascent, physiological state it is not necessarily unwelcome. Problems arise only when the emotion becomes intersubjective and social, 
when it is complicated by social imperatives and social meanings. Sexual desire comes to Lewisham as a sudden awakening, with a kind of joyful celebration: "Love! The greatest of these. The greatest of all things. Better than fame. Better than knowledge" (19). As a result, "His whole being was irradiated with emotion" (22), so much so that he momentarily loses sight of the schema. In due course, Ethel and Lewisham find themselves on a reckless, impromptu ramble-a day spent wandering in the nearby countryside. The Grundyistic reaction of his school and Ethel's relatives is swift and effective: his employment at the school is terminated, and Ethel is sent back to London, where she is lost to him for two and a half years. These actions reinterpret Lewisham's sexual desire, forcing him to recognize it as a threat to his ambition. This changes the complexion of his desire and makes him bitter: "Sometimes he had moods of intense regret for the folly of that walk. . . . His dream of success and fame had been very real and dear to him, and the realization of the inevitable postponement of his long anticipated matriculation, the doorway to all the other great things, took him abruptly like an actual physical sensation in his chest" (48).

Lewisham learns that impulsive desire is not only proscribed, but that it can undermine rational intention. He is faced with a choice of enemies: whether it is his society's social constraints that have brought him down or whether it is the fault of his own emotions. Although he is frequently critical of late-Victorian society, for the bulk of the narrative he is instead at war with his emotions. A simple scenario illustrates his struggle. Once Lewisham lands in London with a scholarship to a polytechnic, he is stirred with a passion for socialist politics. Nevertheless, when Lewisham buys a scarlet necktie as a public sign of his socialism, he blushes with embarrassment while buying it and then again while wearing it on the street. Lewisham's blush emphasizes his susceptibility to debilitating shame-a shame that undermines any attempt to distinguish himself as part of the politically engaged intelligentsia.

Lewisham fails at every stage to eliminate the resulting emotional incoherence. If shame undermines Lewisham's equilibrium, his desire for Ethel is even more threatening. After he reencounters her in London, his passion for her once again threatens his social and economic ambition. Compelled to spend time with her, Lewisham neglects his studies and courts the loss of his scholarship, leading to an agonizing choice between worldly success and love: "Lewisham saw that it was a case of divergent ways. On the one hand that shining staircase to fame and power, that had been his dream from the very dawn of his adolescence, and on 
the other hand-Ethel" (112). Faced with this dilemma, Lewisham feels as though his "logical processes, his emotions and his imagination [are] playing some sort of snatching game with his will" (97). Lewisham's thrilling and haunting sexual passion is thus fraught with regret, and his ambitions undercut the joy of having his sexual desire reciprocated by Ethel. Most painful to him is the sense of class consciousness his love for Ethel initiates. By loving her, "He fell foul of his upbringing. Men of the upper and middle classes . . . were properly warned against involving themselves in this love nonsense before they were independent" (112).

The novel is something of a thought experiment for Wells, who wonders whether emotions can ever be rationalized and controlled, especially when desire and ambition begin to mutate into one another. Wells's pessimistic answer to his own question emerges from the Lewishams' first difficult year of marriage. At first Lewisham tries to see the quick marriage in reckless, rebellious terms: "We are Fighting the World," he tells Ethel, "All the world is against us - and we are fighting it all" (148). But in seeking to balance social imperatives and his new marriage, Lewisham identifies his passion for his wife as the problem and so turns his anger away from the social system and toward Ethel. We see some tendency to blame her early on after they have been castigated for their teenage ramble. Dwelling on the negative consequences of their ramble, "He flung the pen on the floor and made a rush at an ill-drawn attempt upon a girl's face that adorned the end of his room, the visible witness of his slavery. He tore this down and sent the fragments of it scattering" (49). Later, his marriage means he must leave what seems to him the relatively classless space of the university for the humiliations of a marketplace that doesn't want a young, married instructor without a degree. When it becomes clear that his impetuous marriage will end his education, Lewisham's rage intensifies: "He found himself fenced in on every side. A surging, irrational rage seized upon him" (204); "His rage exploded" (205); "Disappointment and exasperation darkened Lewisham's soul. He began to feel angry with everything-even with her" (214); "He took refuge in anger" (223); "Lewisham gave way to a transport of anger" (223); "He had a silent ecstasy of rage" (226). Finally, in a fit of misdirected jealousy, he severely wounds Ethel: "'I have found out you are shallow, you don't think, you can't feel things that I think and feel'" he tells her (223). He finds comfort in the power his rage gives him, for "he knew quite clearly that he was inflicting grievous punishment and that gratified him" (226).

The novel demonstrates Wells's uneasy relation to domesticity 
as a locus of both sexual sustenance and dangerous emotions. Lewisham proves that he can be cruel and can use the privacy of domestic space to reverse the power dynamics of his humiliation in the social world. Yet it is partly through the process of reflecting on his rage and watching its damaging effects on someone who loves him that Lewisham forms a reflective, introspective self that transcends those of the more obtuse clerks of Wells's other novels. It is not that he becomes less vexed; instead, his developing love-and the sense it gives him of his beloved's emotions-affords some perspective on the loneliness implicit in his anger and ambitiousness. ${ }^{9}$ This new understanding enables a reflective skepticism and a new appreciation of ambivalence. He comes to terms, for example, with the inadequacy of his schema and the consequences of his physical desire. He sees the former as a "boy's vanity," a dream of uncommonness that is by necessity swept away with maturity; the latter, in contrast, leads to a domesticity that confirms his commonness, his class, the life for which he was "made and born" (251).

The final events of Love and Mr. Lewisham may express Wells's own dread of "Domestic claustrophobia, the fear of being caught in a household," as he informs us in his autobiography (Experiment 468). But these tensions add to the novel's ambivalence. Lewisham's experience of being "two-sided"-both "commonplace" and capable of great thingsis equally ambivalent, as is his last act of meditatively tearing up the schema. Destroying the schema is a sign of his self-awareness and maturity as much as it points to his failure. As he tidies up the pieces of the torn schema, he is both a newly self-governing man and the personification of a domestic man destined to fade into insignificance. These contradictory meanings are precisely the point, however, for even if Lewisham has circled back to the constraints of his class, his negative capability points to the richness and diversity of his emotional life.

\section{Home Is Where the Hatred Is}

The equipoise established in Love and Mr. Lewisham is short-lived. The History of Mr. Polly (1910) presents an endgame in the emotional lives of Wells's clerks and concludes his novelistic exploration of their emotions. Polly is also Wells's most misanthropic social comedy. The protagonist, Alfred Polly, ends up burning down his small outfitter's shop and home and then abandoning his wife. In this novel, the weight of the material world on the lower middle class creates unbearable feelings that cannot be 
managed or contained. In Polly's domestic world there is not enough sexual energy or domestic contentment to override his class frustrations. Polly repudiates the normative, social world, but instead of withdrawing into a satisfying domesticity, he moves from the domestic to an awe-struck natural aesthetic. In so doing, he signals the exhaustion of more familiar personal emotions as a remedy for the difficulties of lower-middle-class life.

Ironically for a narrative that ends with a kind of existential detachment, the novel is primarily about recklessness. Polly's reckless disregard of the future leads him to marry haphazardly and to take on the debt of a small shop. When the novel opens, Polly is a disillusioned thirty-seven-year-old, with a failed marriage and a bankrupt shop. As a proprietor/clerk, Polly ought to be as content as Kipps, who by the end of his novel looks forward to a future filled with small satisfactions. Instead, Polly is consumed with frustration. By way of introduction, we find him in a great fury storming out of the second-floor apartment he shares with his wife: he "hated the whole scheme of life-which was at once excessive and inadequate of him. He hated Fishbourne, he hated Fishbourne High Street, he hated his shop and his wife and his neighbours-every blessed neighbour-and with indescribable bitterness he hated himself" (2). To be sure, forms of hatred appear in the other social comedies. Kipps does not only learn to love, he also learns to despise the drapers' shop, to hate Helen Walshingham, to scorn the Londoners "laughing at him behind his back" (210), and to feel "the smouldering fires of rebellion" (241) against the attendees of a tea party, "collectively and in detail" (250). Lewisham's rage, as well, expresses antisocial tendencies. But neither Kipps nor Lewisham rejects the social world outright. They both attempt to rebel but ultimately accept the social conditions and habitus that made them. This form of acceptance has failed for Polly, resulting in his repudiation of any sort of normative life. As Christopher Lane writes of Joseph Conrad, Wells "shows why a character would be drawn to forms of satisfaction, like violent self-annihilation, that are psychically appealing and liberating, even as they result in awful bodily and social harm" (Lane 173). Polly suggests, more even than Lewisham, that class-based rage is as much about renunciation as reform.

In pointing out that hating the "whole scheme of life" is "at once excessive and inadequate," the narrator suggests that Polly's hatred is both too far-reaching and too impotent, simultaneously overwrought and passive. We learn later in the novel that Polly's hatred and disgust are directed toward the "passive endurance of dullness 
throughout the best years of his life" (117) and that "he came to hate the very sight" of his fellow shopkeepers because they echo "his own stagnation" (111). Polly's passivity embodies what Ngai describes as an "ugly feeling" (2), which expresses "restricted" or "suspended" agency (12). For Ngai, these ugly feelings do "not so much solve the dilemma of social powerlessness as diagnose it powerfully . . preparing us for more instrumental or politically efficacious emotions" (353-54). Wells's social comedies diagnose many of the sources of social powerlessness, but it is less clear if the emotions they describe succeed in being politically efficacious. What is clear is that Polly is even less successful then either Kipps or Lewisham in its diagnosis, for the novel so overdetermines Polly's escape from the normative world that he ultimately sees himself as a "Visitant from Another World" (178).

Polly repudiates the world of bodies and their needs, of responsibility and work. His reckless (and botched) suicide attempt symbolically cuts him free from these pressures as well as from the emotions they inspire. Like Lewisham's decision to marry in the face of social disapproval, Polly's is partially an act of self-determination in the face of social forces that demand hypocrisy and submission. He becomes something of a domesticated wild man, a handyman for the female owner of a rural river inn, in a situation that provides a space for his newfound awe toward nature.

The possibility of meaningful existence, however-such as that found by Kipps and Lewisham-is limited in Polly's new world. The best example of this comes in a series of encounters with the innkeeper's nephew, Jim, a brutish drunk who sees Polly as an intruder. Jim's narcissism and potential for violence personifies the indifference of nature. He thus forces Polly to confront savage and irrational forces that require no more than cunning to survive. Polly's former wife, Miriam, is similarly indifferent. When he returns guiltily to Fishbourne, after five years, to see what has become of his previous life, Miriam is only concerned with losing the insurance settlement on his life; "I'd always feared you'd come back," she says (178).

When Polly describes his understanding of the meaning of life at the end of the novel, he is strikingly unsentimental:

\footnotetext{
One seems to start in life . . expecting something. And it doesn't happen. And it doesn't matter. One starts with ideas that things are good and things are bad-and it hasn't much relation to what is good and what is bad. I've always been the skepta-
} 
ceous [sic] sort, and it's always seemed rot to me to pretend men know good from evil. It's just what I've never done. No Adam's apple stuck in my throat, Ma'am. (180)

With bravado in his voice, Polly claims to see life in its stark reality, not only beyond human values such as good and evil but beyond human emotions as well.

But Polly's conclusion places Wellsian emotion in an awkward bind. On the one hand, emotional responses must be "fierce" and "real" in order to be legitimate (Experiment 537); on the other, they must avoid sentiment, the lump in one's throat. Throughout all of the social comedies, Wells is never quite sure if he wants recklessness or only the idea of recklessness. In Polly, he attempts to solve this dilemma with a response to the natural world that emphasizes nature's indifference and hence the legitimacy of human skepticism. That is to say, nature replaces powerlessness in the face of class-based shame with powerlessness in the face of nature. By helping him sustain a disinterested approach to his circumstances, nature's indifference teaches Polly not to be ashamed or disappointed.

Polly represents something of a failure in Wells's oeuvre of the social comedy. In it, socioeconomic pressures become too great and the domestic too weak an alternative. It is true that when Wells looks closely at class in his social comedies he sees not a political problem but an emotional one. Polly is perhaps the logical and distorted extension of this tendency, especially for an author so ambivalent about his own emotions. The novel ends up in an abstract utopian space in which the messy details of clerkly emotion have been displaced. Rather than a matter of the daily conditions of existence, materiality is converted into a brute force of nature.

And yet, what we might call Wells's critique of emotion offers a model for understanding the nuances of class experience and even for rethinking our opinions of the lower middle class. Kipps and Lewisham come to terms with their conditions of existence in ways that bring satisfaction and delight as well as disappointment and pain. Moreover, Kipps and Love and Mr. Lewisham signify a moment when Victorian domesticity-under fire from such figures as Gissing, Ibsen, and Hardy-was reimagined as vital and pleasurable, with many of its faults acknowledged. With Polly, Wells renounces the shame that make his clerks seem to care so much, the desires that tie them to their class and the constrained worlds of their everyday lives. Wells was not to write 
another novel of lower-middle-class life quite like the social comedies. In his novels, at least, Wells moved beyond his own emotions of class.

Indiana University

\section{NOTES}

${ }^{1}$ For a discussion of the various interpretations of the Lover-Shadow, see Lynn's Shadow Lovers, especially xxii, 23-24. Lynn suggests that because of his lower-middleclass background, Wells sought validation from his mostly aristocratic and uppermiddle-class lovers. For analysis of the Lover-Shadow's psychosexual ramifications, see Steffen-Fluhr.

${ }^{2}$ The phenomenon of self-difference (the mind against itself, or the self against the world), illustrated by this example, is essential to Terada's analysis of the nonsubjective nature of emotion: "Such emotion can no longer verify unities, but then it no longer has to; indeed, it has not to" (86).

${ }^{3}$ The portrait of emotions of class I develop below owes much to Steedman, whose history of her mother, Landscape for a Good Woman, is "about people wanting . . . things, and the structures of political thought that have labeled this wanting as wrong" (23).

${ }^{4} \mathrm{On}$ the rapid rise of the lower middle class, see Anderson and Crossick. Sanders, Wild, Augst, and Young provide recent literary studies of the lower middle class. Felski calls for further work.

${ }^{5}$ Women do, of course, feel these emotions as well in Wells's realist fiction, but this set of novels focuses on male protagonists. Ann Veronica (1909), Wells's New Woman novel, portrays a similar set of classed emotions in women.

${ }^{6}$ Recklessness appears in other guises during the late Victorian period: in Gissing, as sign of cultural degeneration; and in Hardy, as a manifestation of fate. Indeed, later forms of recklessness compete with cultural modernism's confidence in technique and disinterest. In my reading of Wells, recklessness offers the possibility of agency that Massumi identifies with "intensities," affects that are "unformed and unstructured" by language or culture (260; see also Ngai 25-27; Sedgwick 18).

${ }^{7}$ In her study of working-class autobiographies, Gagnier looks at a similar way in which more "significant selves" emerge (28).

${ }^{8}$ Rashness suggests that an individual is vital and risk-taking and that he or she could (for a moment, at least) forget about the economic consequences of his or her actions. For another perspective on rashness, see Fisher, who argues that it can be a legitimate form of justice even though it momentarily suspends deliberative, rational judgment (100-03).

${ }^{9} \mathrm{Ablow}$ points to a similar process in Dickens, who she claims develops an ethic from the "work that love encourages one to perform on oneself" (24).

\section{WORKS CITED}

Ablow, Rachel. "Labors of Love: The Sympathetic Subjects of David Copperfield." Dickens Studies Annual 31 (2002): 23-46. 
Anderson, Gregory. "The Social Economy of Late-Victorian Clerks." The Lower Middle Class in Britain 1870-1914. Ed. Geoffrey Crossick. London: Croom Helm, 1977. 113-33.

Augst, Thomas. The Clerk's Tale: Young Men and Moral Life in Nineteenth-Century America. Chicago: U of Chicago P, 2003.

Bourdieu, Pierre. Distinction: A Social Critique of the Judgment of Taste. Trans. Richard Nice. Cambridge: Harvard UP, 1984.

Crossick, Geoffrey. "The Emergence of the Lower Middle Class in Britain: A Discussion.” The Lower Middle Class in Britain 1870-1914. Ed. Crossick. London: Croom Helm, 1977. 11-60.

Felski, Rita. "Nothing to Declare: Identity, Shame, and the Lower Middle Class." PMLA 115 (2000): 33-45.

Fisher, Philip. The Vehement Passions. Princeton: Princeton UP, 2002.

Foote, Stephanie. "Resentful Little Women: Gender and Class Feeling in Louisa May Alcott." College Literature 32.1 (Winter 2005): 63-85.

Fowler, Bridget. "Obituary: Pierre Bourdieu." The Independent. 1 Feb. 2002. <http://www .independent.co.uk/news/obituaries/pierre-bourdieu-729717.html>. 5 Feb. 2008.

Gagnier, Regenia. Subjectivities: A History of Self-Representation in Britain, 1832-1920. Oxford: Oxford UP, 1991.

Green, Benny. "Introduction.” Kipps. H. G. Wells. Oxford: Oxford UP, 1984. 1-10.

Gross, Daniel M. The Secret History of Emotion: From Aristotle's "Rhetoric" to Modern Brain Science. Chicago: U of Chicago P, 2006.

Hammerton, A. James. "Pooterism or Partnership? Marriage and Masculine Identity in the Lower Middle Class, 1870-1920.” Journal of British Studies 38.3 (1999): 291-321.

Lane, Christopher. Hatred $\mathcal{E}$ Civility: The Antisocial Life in Victorian England. New York: Columbia UP, 2004.

Lynn, Andrea. Shadow Lovers: The Last Affairs of H. G. Wells. Cambridge, MA: Westview P, 2001.

MacKenzie, Norman. "Introduction.” The History of Mr. Polly. H. G. Wells. London: J. M. Dent, 1993. xxix-xxxvii.

Massumi, Brian. Parables for the Virtual: Movement, Affect, Sensation. Durham: Duke UP, 2002.

Ngai, Sianne. Ugly Feelings. Cambridge: Harvard UP, 2005.

Orwell, George. Coming Up for Air. London: Secker \& Warburg, 1971.

Sanders, Lise Shapiro. Consuming Fantasies: Labor, Leisure, and the London Shopgirl, 1880-1920. Columbus: Ohio State UP, 2006.

Sedgwick, Eve Kosofsky. Touching Feeling: Affect, Pedagogy, Performativity. Durham: Duke UP, 2003.

Sennett, Richard, and Jonathan Cobb. The Hidden Injuries of Class. New York: W. W. Norton, 1993.

Steedman, Carolyn. Landscape for a Good Woman: A Story of Two Lives. New Brunswick: Rutgers UP, 1987.

Steffen-Fluhr, Nancy. "Women and H. G. Wells." Critical Essays on H. G. Wells. Ed. John Huntington. Boston: G. K. Hall, 1991. 148-69.

Terada, Rei. Feeling in Theory: Emotion after the "Death of the Subject". Cambridge: Harvard UP, 2001. 
Wells, H. G. Experiment in Autobiography. 1934. 2 vols. London: Faber and Faber, 1984.

- H. G. Wells in Love: Postscript to an Experiment in Autobiography. London: Faber and Faber, 1984.

. The History of Mr. Polly. 1910. London: J. M. Dent, 1993.

Kipps. 1905. Oxford: Oxford UP, 1984.

—. Love and Mr. Lewisham. 1900. Oxford: Oxford UP, 1983.

Wild, Jonathan. The Rise of the Office Clerk in Literary Culture, 1880-1939. Basingstoke: Palgrave Macmillan, 2006.

Young, Arlene. Culture, Class and Gender in the Victorian Novel: Gentlemen, Gents and Working Women. New York: St. Martin's, 1999. 